\title{
Effects of Brood Pheromone Modulated Brood Rearing Behaviors on Honey Bee (Apis mellifera L.) Colony Growth
}

\author{
Ramesh R. Sagili • Tanya Pankiw
}

Revised: 26 November 2008 / Accepted: 20 February 2009 /

Published online: 10 March 2009

(C) The Author(s) 2009. This article is published with open access at Springerlink.com

\begin{abstract}
A hallmark of eusociality is cooperative brood care. In most social insect systems brood rearing labor is divided between individuals working in the nest tending the queen and larvae, and foragers collecting food outside the nest. To place brood rearing division of labor within an evolutionary context, it is necessary to understand relationships between individuals in the nest engaged in brood care and colony growth in the honey bee. Here we examined responses of the queen, queenworker interactions, and nursing behaviors to an increase in the brood rearing stimulus environment using brood pheromone. Colony pairs were derived from a single source and were headed by open-mated sister queens, for a total of four colony pairs. One colony of a pair was treated with $336 \mu \mathrm{g}$ of brood pheromone, and the other a blank control. Queens in the brood pheromone treated colonies laid significantly more eggs, were fed longer, and were less idle compared to controls. Workers spent significantly more time cleaning cells in pheromone treatments. Increasing the brood rearing stimulus environment with the addition of brood pheromone significantly increased the tempo of brood rearing behaviors by bees working in the nest resulting in a significantly greater amount of brood reared.
\end{abstract}

Keywords Brood pheromone honey bee - queen-worker interactions · brood rearing behaviors $\cdot$ colony growth

\section{Introduction}

Social insect brood rearing systems present a unique set of evolutionary models because workers that rear young do not generally reproduce. Additionally, brood

R. R. Sagili $(\bowtie)$

Department of Horticulture, Oregon State University, Corvallis, OR 97331-7304, USA

e-mail: rare@tamu.edu

T. Pankiw

Department of Entomology, Texas A\&M University, College Station, TX 77843-2475, USA 
rearing labor is divided among the existing workforce, such that some individuals work outside the nest foraging to meet the nutritional needs of the colony, and others work inside the nest directly caring for young and maintaining the nest. Much like individual whole organisms, honey bee colonies undergo a process of growth, development, and reproduction. For social insect colonies, colony-level growth and reproduction are the principal sources of fitness. As such, much of individual worker and colony behaviors are ultimately related to colony growth leading to colony level reproduction. A honey bee colony has only one queen and the majority of her eggs develop into functionally sterile workers. Colony growth is achieved through increased queen-egg laying rate and intensity of brood rearing labor. Houston et al. (1988) presented a model investigating the amount of effort individual workers should devote to foraging to maximize colony fitness. The model predicts that individual workers and colonies should respond to an increased demand for resources by working harder. Houston et al. (1988) also predicted that manipulating the amount of brood should increase the brood rearing efforts of colonies.

The labor of honey bee brood rearing may be viewed as divided among bees that forage for food outside the nest and those that work in the nest. Foraging effort associated with changes in colony demand for food resources has been investigated in depth. Increasing the amount of larvae results in increases in the number of pollen foragers and pollen load weights returned (Al-Tikrity et al. 1972; Free 1979; Eckert et al. 1994). Pollen foraging activity level decreases in response to the addition of stored pollen and increases in response to the removal of stored pollen (Free 1967; Danka et al. 1987; Camazine 1993; Dreller and Tarpy 2000). Increasing the amount of stored pollen in colonies concurrently increases brood rearing and decreases pollen foraging (Fewell and Winston 1992). Colonies also show corresponding responses to the fatty acid esters extractable from the surface of larvae, called brood pheromone, apparently estimating amount of larvae from amount of brood pheromone. Adding brood pheromone to colonies increases number of pollen foragers by up to $150 \%$, significantly increases pollen load weight returned by individual pollen foragers, significantly increases the number of pollen grains extractable from the bodies of non-pollen foragers, and brood pheromone significantly increases the number of pollen forager trips per unit time (Pankiw et al. 1998; Pankiw and Page 2001; Pankiw 2004a; Pankiw 2004b; Pankiw et al. 2004; Pankiw 2007). Addition of brood pheromone to colonies increases amount of incoming pollen through a number of behavioral mechanisms, while colony rate of growth concurrently increases over a 4 week period measured as amount of brood area reared (Pankiw et al. 2004; Pankiw et al. 2008). This strongly suggested that along with increased pollen foraging effort, there was increased brood rearing effort by workers in the nest.

Change in brood rearing effort by bees working in the nest with change in amount of brood has received far less attention than that of foraging effort. In the nest, workers regulate queen egg laying rate through the quantity and quality of food workers provision to the queen (Chauvin 1956; Allen 1960). The rate at which wax comb cells are prepared by workers for queen acceptance for egg deposition is another mechanism through which workers regulate queen egg-laying rate (Free \& Williams 1972). Stored pollen is consumed by nurse bees that use the proteins derived from the pollen to produce proteinaceous hypopharyngeal gland secretions 
that are fed to developing larvae (Crailsheim et al. 1992). Larval cues and pollen are necessary for hypopharyngeal gland development, activity, and protein production (Brouwers 1982; Brouwers 1983; Huang and Otis 1989; Huang et al. 1989; Mohammedi et al. 1996; Hrassnigg and Crailsheim 1998). Brood pheromone may stimulate hypopharyngeal gland development even in the absence of a pollen diet (Mohammedi et al. 1996). However a protein source is necessary for glandular protein biosynthesis resulting in greater amounts of extractable protein (Brouwers 1983; Huang and Otis 1989; Huang et al. 1989; Mohammedi et al. 1996). Addition of brood pheromone to colonies also increases amount of protein extractable from nurse-aged bee hypopharyngeal glands (Pankiw et al. 2004). Here we test the prediction by Houston et al. (1988) that the brood rearing efforts of bees working in the nest should increase in response to an increase in the perceived amount of larvae in the colony. Synthetic brood pheromone was used to increase the perception of amount of larvae in the experimental colonies.

\section{Materials and Methods}

This study was carried out using colonies housed in observation hives during the months of June \& July 2005, in an apiary located at the Texas A\&M University Riverside campus, College Station, Texas. This experiment was replicated four times and had two treatments; brood pheromone and control. A pair of colonies was derived by dividing a single colony. Each colony in a pair consisted of approximately 4,000 workers headed by a naturally mated queen such that queens of a pair were sisters. Each colony was installed in a four-frame observation hive (Gary and Lorenzen 1976). Five days prior to beginning the experiment, 200 newly emerged bees derived from the original parental source were added to each pair. Individual bees were uniquely identified with a plastic colored number tag (BioQuip Products Inc. 1172, CA, USA) glued to the thorax and a color mark on the abdomen (Seeley and Kolmes 1991). At the onset of the experiment each colony contained 1 Langstroth deep frame of honey $\left(877 \mathrm{~cm}^{2}\right)$, one half frame of pollen, and the remaining area comprised empty cell space. The queen was confined to a single frame for a period of 3 days using queen excluding material. Worker bees were able to pass through the queen excluder material and freely move throughout the colony. One frame provided the queen with nearly 5,000 cells to deposit individual eggs. On average, in larger colonies, queens lay fewer than 1,500 eggs per day (Winston 1987), therefore we did not limit egg laying space in a 3-day period. After the 3-day period the queen was switched to another empty frame for 3 more days.

One colony of a pair received $336 \mu \mathrm{g}$ of brood pheromone (BP) daily for 9 days (Pankiw 2004a). The fatty acid ester blend of brood pheromone used here was as follows: $1 \%$ ethyl linoleate, $13 \%$ ethyl linolenate, $8 \%$ ethyl oleate, $3 \%$ ethyl palmitate, $7 \%$ ethyl stearate, $2 \%$ methyl linoleate, $21 \%$ methyl linolenate, $25 \%$ methyl oleate, 3\% methyl palmitate, and 17\% methyl stearate. The other colony received a glass plate that had been rinsed with 2-propanol (EMD Chemicals Inc. PX1835-5, Gibbstown, NJ, USA). The treatments were delivered on a glass plate $(9.5 \mathrm{~cm} \times 5 \mathrm{~cm})$. The 2-propanol was completely evaporated prior to inserting glass plates in to hives. The glass plates were inserted through a port installed in 
a wall of each hive in such a way that it didn't interfere with bee activities or observations.

\section{Queen Observations}

Each day we digitally recorded (Sony DCR-TRV70) the queen for $2 \mathrm{~h}$ in the morning and $2 \mathrm{~h}$ in the afternoon. The following behavioral categories were recorded: (1) idle: the queen was motionless on the comb and moved only her antennae or individual legs. Retinue bees groomed or licked her, but no food was given (2) Patrolling: the queen walked across the comb at a speed greater than $5 \mathrm{~mm} / \mathrm{s}$ and (often) inspected cells. (3) Receiving food: the queen extended her proboscis between the mandibles of a worker for more than 5 s (Allen 1960). (4) Egg laying: after a brief inspection of an empty cell, the queen inserted her abdomen into the cell to lay an egg. Each day a map tracing of the area of eggs, larvae and pupae was drawn on a transparent sheet for each hive. Daily mapping continued for about 9 days when the immatures of the first frame pupated and were sealed over with wax. Data from the maps were used to calculate egg laying rate, numbers of larvae, and total brood areas.

\section{Larval Observations}

We digitally recorded nursing times for five selected larvae from each age class (instar), that is, 2- and 5-day old for $30 \mathrm{~min}$, once in the morning and once in the afternoon for each colony. The reason for choosing these two ages was that 2-day old larvae are in an early stage of development but large enough to be seen and 5-day larvae are near the end of larval development and are the greatest food consumers. Young larvae exclusively receive brood food, while older larvae receive some pollen and honey along with brood food (Winston 1987). The map tracings were used to locate such larvae on a daily basis. A bee was defined as nursing if she inserted her head and part of her thorax inside a cell containing a larva. Additionally, a nursing bee was distinguished from one that was inspecting or cleaning an empty cell by duration of the act. A nursing act is defined as lasting between 3 s and 3 min (Lindauer 1952; Huang and Otis 1991; Schmickl et al. 2003).

\section{Nurse Bee Observations}

Each day we randomly selected 5 number tagged workers per colony and observed each for a total of $15 \mathrm{~min}$, recording nursing bouts, cell inspections, and cell cleaning. The following variables were measured after Schmickl et al. (2003). (1) nursing time, (2) inspection, is defined as a bee inserting her head and part of her thorax in an empty cell for $\leq 3 \mathrm{~s}$ (Lindauer 1952). Cell inspection may lead to cell cleaning behavior, an act that prepares a cell to accept an egg (Winston 1987). (3) Cell cleaning, is defined as a bee entering an empty cell, as above, for a duration $>3 \mathrm{~s}$.

Ten nurse bees from the brood nest area were selected randomly from each colony on days 3, 6 and 9 for analyzing protein content of hypopharyngeal glands. Protein content of hypopharyngeal glands of nurse bees was measured using the Bradford 
assay as per Sagili et al. (2005). Briefly, hypopharyngeal glands were homogenized using a homogenizer that tightly fitted in microcentrifuge tubes used to store the glands. Subsequently, tubes were centrifuged at $1000 \mathrm{rpm}$ for $2 \mathrm{~min}$. Supernatant from each tube was used for analysis. The 500-0202 Quick Start Bradford Protein Assay Kit 2 was used (Bio-Rad Laboratories, CA, and U.S.A.). We added 2 or $5 \mu \mathrm{l}$ from each sample to be analyzed to microcentrifuge tubes containing $1 \mathrm{ml}$ Bradford reagent. Tubes were vortexed to homogenize the contents, and then incubated for $5 \mathrm{~min}$ at room temperature. Standard-curves were prepared using bovine serum albumin (BSA). Protein absorbance was measured at $595 \mathrm{~nm}$ against blank reagent using a Beckman Spectrophotometer (Model \#D4-640, Beckman Instruments, Inc., Columbia, MD, USA). Weight of protein (BSA) was plotted against the corresponding absorbance value to generate a linear regression equation (SAS PROC REG; SAS 2000). Protein extracted from hypopharyngeal glands was estimated using the linear regression equation generated from the BSA standard curve.

\section{Statistical Analysis}

Frequency data was analyzed using the Mann-Whitney Test and timed variables were analyzed using $t$-test (Sokal and Rohlf 1995). Protein quantity of hypopharyngeal glands was also analyzed using $t$-test. Repeated-measures ANOVA was used to analyze brood area (Sokal and Rohlf 1995).

\section{Results}

\section{Queen Observations}

In all 4 replications, total number of eggs laid by queens in brood pheromone treated colonies over the 9-day experimental period was significantly greater $(\operatorname{Rep} 1: U=1$, $P<0.0001$; Rep2: $U=11.5, P<0.01$; Rep3: $U=2, P<0.001$; Rep4: $U=3, P<0.001$; Fig. 1).

Fig. 1 Mean number of eggs laid by the queen in a period of 9 days $(+\mathrm{SE})$ in control and brood pheromone treatments. Asterisks indicate significant difference.

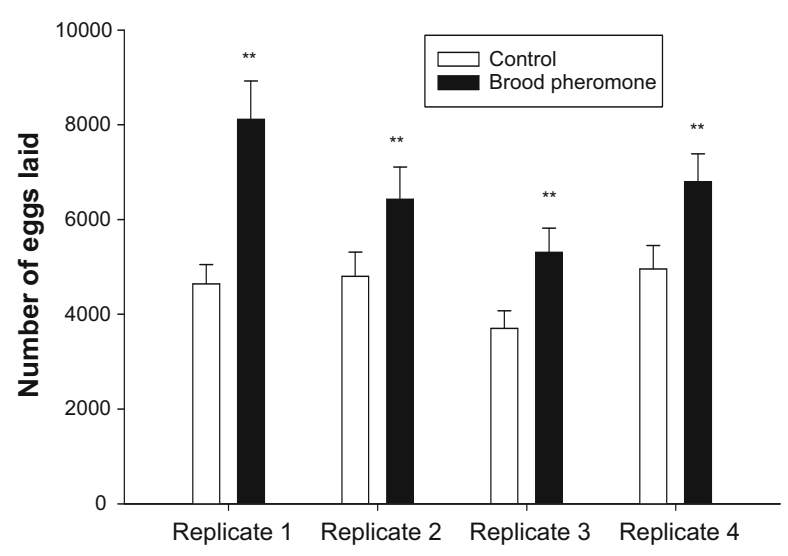


Fig. 2 Mean feeding time of queen (seconds) in an observation period of $1 \mathrm{~h}(+\mathrm{SE})$ in control and brood pheromone treatments. Asterisk indicates significant difference.

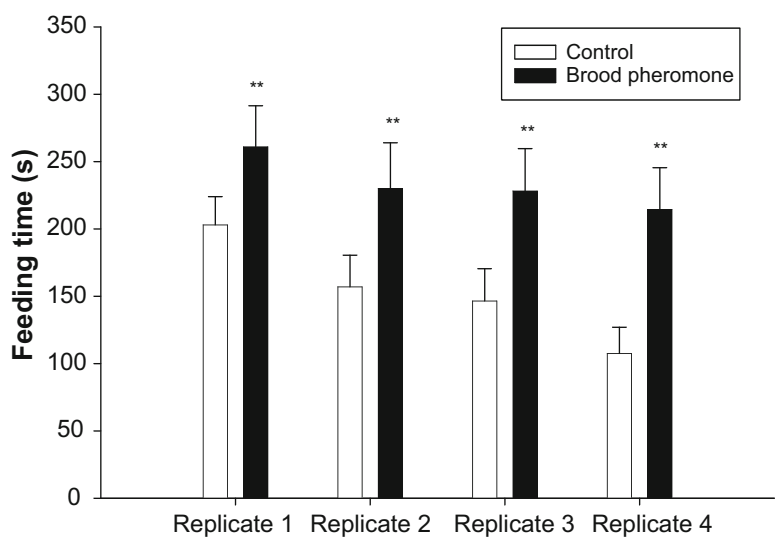

Frequency of feeding bouts was not significantly different between treatments in all replications (Rep1: Mann-Whitney $U=347.5, P=0.12$; Rep2: $U=372, P=0.24$; Rep3: $U=338, P=0.09$; Rep4: $U=352, P=0.13$ ). Total amount of time spent feeding the queen however was significantly greater in brood pheromone treated colonies (Rep1: $t=2.42, d f=70, P<0.01$; Rep2: $t=3.12, d f=70, P<0.001$; Rep3: $t=2.58, d f=$ 70, $P<0.01$; Rep4: $t=5.82, d f=70, P<0.0005$; Fig. 2 ).

Queen idle time was significantly lower in the brood pheromone treatment versus the control (Rep1: $t=7.95, d f=70, P<0.0005$; Rep2: $t=2.42, d f=70, P<0.01$; Rep3: $t=3.22, d f=70, P<0.001$; Rep4: $t=3.31, d f=70, P<0.001$; Fig. 3). Queen patrolling time, presumably seeking a cell to lay an egg was significantly greater in the brood pheromone treatment (Rep1: $t=9.58, d f=70, P<0.0005$; Rep2: $t=2.49, d f=70, P<$ 0.01; Rep3: $t=3.19, d f=70, P<0.001$; Rep4: $t=2.41, d f=70, P<0.01$; Fig. 4).

Nurse Bee and Larval Observations

Amount of time spent by nurse bees inspecting and nursing larvae was not significantly different between brood pheromone and control treatments in all four replications (Inspection: Rep1: $t=0.67 ; d f=88, P=0.258$; Rep2: $t=1.31, d f=88, P=$

Fig. 3 Mean idle time of queen (seconds) in an observation period of $1 \mathrm{~h}(+\mathrm{SE})$ in control and brood pheromone treatments. Asterisks indicate significant difference.

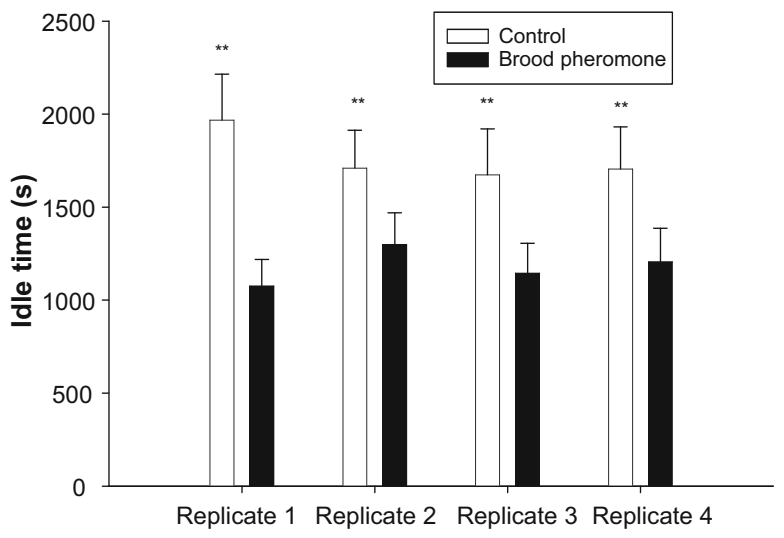


Fig. 4 Mean patrol time of the queen (seconds) in an observation period of $1 \mathrm{~h}(+\mathrm{SE})$ in control and brood pheromone treatments. Asterisks indicate significant difference.

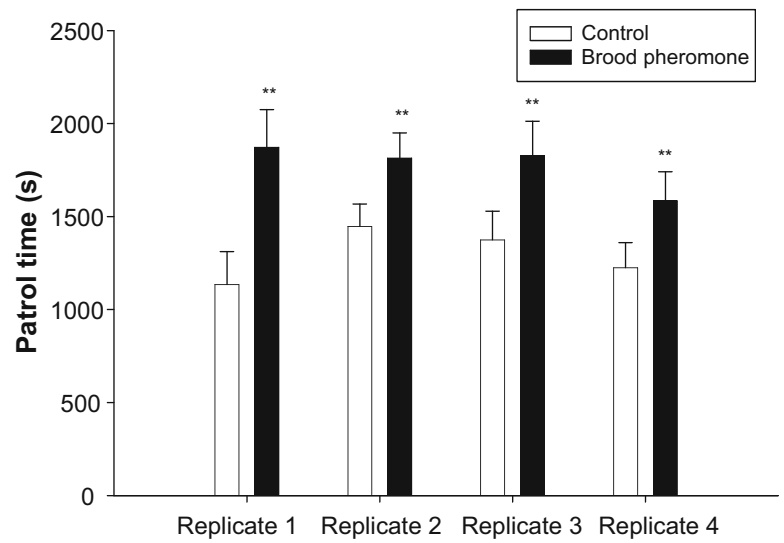

0.09; Rep3: $t=0.64, d f=88, P=0.28$; Rep4: $t=1.36, d f=88, P=0.08$; Nursing: Rep1: $t=0.31, d f=88, P=0.324$; Rep2: $t=0.212, d f=88, P=0.49$; Rep3: $t=0.198, d f=88, P=$ 0.515; Rep4: $t=1.38, d f=88, P=0.08$ ). Bees in the brood pheromone treated colonies spent significantly more time cleaning cells, presumably meeting a demand due to the greater egg-laying rate (Rep1: $t=3.19, d f=88, P<0.001$; Rep2: $t=4.12, d f=88, P<$ 0.0005; Rep3: $t=3.31, d f=88, P<0.001$; Rep4: $t=4.67, d f=88, P<0.0005$; Fig. 5). The amount of time that larvae were fed was not significantly different between brood pheromone and control treatments in all the four replications for both 2-day and 5-day old larvae that were observed ( $t$-test, $P>0.05$ ).

Hypopharyngeal gland protein content was significantly higher in bees treated with brood pheromone compared to control $(t=9.61, d f=238, \mathrm{P}<0.0005 ; \mathrm{BP}=23.7 \pm$ $1.6 \mu \mathrm{g}$; Control=17.4 $\pm 1.1 \mu \mathrm{g})$. Brood pheromone treated colonies reared significantly more brood than the control (Repeated Measures ANOVA: $F_{1,6}=17, P=$ 0.006; Fig. 6). In the BP treatment significant correlation was observed between queen feeding time and the total number of eggs laid by the queen (Pearson correlation coefficient $=0.61, P=0.001)$. There was also a significant correlation between the time workers spent cleaning cells and total number of eggs laid by the queen (Pearson correlation coefficient $=0.56, P=0.001$ ) in $\mathrm{BP}$ treated colonies.

Fig. 5 Mean cell-cleaning time (seconds) in an observation period of $15 \mathrm{~min}(+\mathrm{SE})$. Asterisks indicate significant difference.

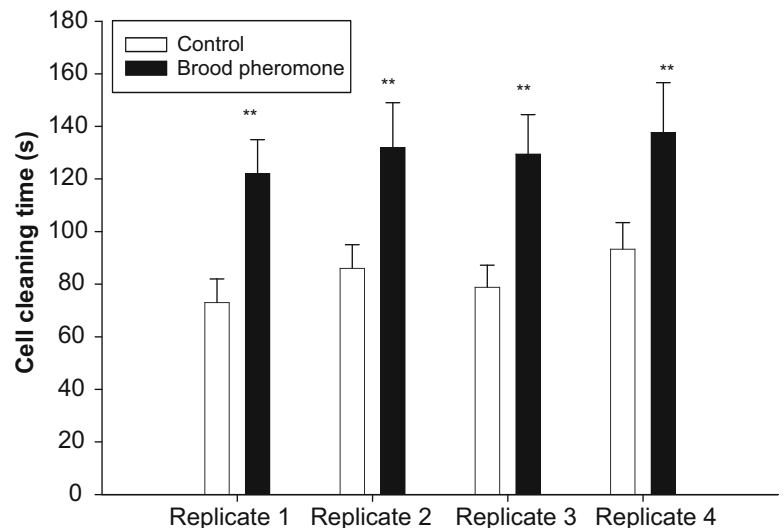


Fig. 6 Mean brood area reared $( \pm \mathrm{SE})$ in brood pheromone and control colonies over a period of 9 days. Asterisks indicate significant difference.

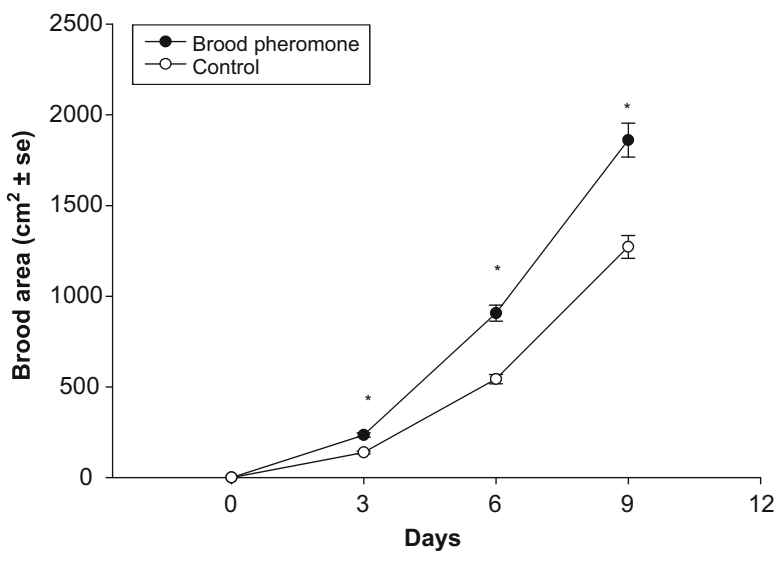

\section{Discussion}

Dramatic differences were observed between colonies treated with brood pheromone and the control for overall number of eggs laid in 9 days, amount of time queens were fed by nurses, amount of time queens were idle, queen patrolling time, amount of time workers cleaned empty cells, and amount of protein extractable from hypopharyngeal glands of nurses. Queens and individual workers adjusted brood rearing behavioral and physiological efforts in response to an increased brood rearing stimulus environment. Consequentially a striking increase in overall rate of colony growth was observed; a fitness trait.

Increasing the brood rearing stimulus environment with brood pheromone resulted in workers feeding the queen for longer periods of time, possibly transferring greater amounts of food. An inference is that queens responded by increasing rate of egg production likely stimulated by an enriched protein environment. This inference is further strengthened by the strong positive correlation observed between queen feeding time and the total number of eggs laid. Though there was a significant difference in total feeding time of queens between pheromone treatment and control, there was no significant difference in feeding frequency. This suggests that total feeding duration is a more reliable measure of amount of food transferred rather than total number of feeding bouts. Allen (1960) also showed that total duration of feeding per hour is a better approximation of the amount of food received by the queen.

Queens in the brood pheromone treated colonies were significantly less idle and patrolled for significantly longer durations, compared to controls. This might be a result of queens spending more time seeking cells in which to lay eggs and egg laying. Significantly more time was spent in cell cleaning by workers in brood pheromone treated colonies. Addition of brood pheromone increased the brood rearing stimulus environment affecting a wide spectrum of workers and behaviors; increases number of pollen foragers, increases pollen load weights returned, increases number of pollen grains extractable from non-pollen foragers, increases number of pollen foraging trips per unit time (Pankiw et al. 1998; Pankiw and Page 
2001; Pankiw and Rubink 2002; Pankiw 2004a; Pankiw 2004c; Pankiw et al. 2004; Pankiw 2007). To this list we now may add behaviors performed by bees working in the nest such as cleaning cells and feeding the queen.

Hypopharyngeal gland protein content was significantly greater in nurse bees sampled from brood pheromone treatment, indicating an increased protein nutritional environment. The significantly greater brood areas observed in brood pheromone treated colonies appeared to be a consequence of higher egg laying rate and increased protein environment. Pankiw et al. (2004, 2008) reported similar results, where colonies treated with brood pheromone daily for 28 days reared significantly more brood, and hypopharyngeal gland protein content of nurse bees was significantly higher than the controls. Results here point to increases in multiple brood rearing related worker-queen interactions in pheromone treated colonies that are induced by an increased brood rearing stimulus environment, which consequentially lead to a steeper colony growth trajectory.

Increased queen egg laying in response to an increased brood pheromone stimulus is counter-intuitive. However, workers regulate queen egg laying rate through quantity and quality of food provisioned to the queen (Chauvin 1956; Allen 1960). Colonies undergo a process of growth and development ultimately leading to colony-level reproduction. Houston et al. (1988) referred to the phases of colony growth as "ergonomic and reproductive", whereby colonies in the ergonomic phase are working toward a reproductive phase. The exact developmental stage of a colony is a function of many factors, thus for any given stage of development there will be quantifiable states of population size, adult worker demographic structure (i.e. foragers to non-foragers), amount of brood, and stored food. These states are properties of the colony's developmental stage. Changes in any of these properties may change a colony's developmental stage along with corresponding changes in colony-level and individual forging behaviors, worker brood rearing effort, and hypopharyngeal gland physiology. For example, probability of colony-level reproduction increases with increases in colony population (Lee and Winston 1987; Fefferman and Starks 2006). Changes in colony demographic structure changes colony state such that, removal of foragers increases the rate of foraging behavior development of non-foragers, and removal of nurses delays foraging ontogeny of non-foragers as well as the reversion of some foragers to nursing tasks (Huang and Robinson 1996). Chemical cues extractable from the surface of foragers and non-foragers have been demonstrated to communicate colony demographic structure, where addition of forager extracts delays age of first foraging, and addition of non-forager extracts accelerates age of first foraging among young workers (Pankiw 2004c). Addition of brood pheromone increases multiple colony-level and individual pollen foraging efforts, and rate of colony growth (Pankiw et al. 1998; Pankiw and Page 2001; Pankiw 2004a; Pankiw 2004b; Pankiw et al. 2004; Pankiw 2007). One of the important mechanisms employed by colonies to estimate amount of larvae is by amount of brood pheromone. Colony-level brood rearing behaviors apparently were also adjusted according to amount of brood pheromone, correspondingly affecting colony growth rate. It strongly suggests that queen egg laying rate is concurrently adjusted to match the perceived colony state for amount of larvae, increased incoming pollen and rate of colony growth (Houston et al. 1988; Schmid-Hempel et al. 1993; Fefferman and Starks 2006). 
Much of individual and colony-level behaviors are ultimately related to colony development, growth, and reproduction. In the honey bee, rate of colony growth is primarily determined by the workforce available to support the current adult and immature population and queen egg laying rate. Increased rate of colony growth occurs when both the adult workforce brood rearing efforts and queen egg laying rate are increased. However, it can be predicted from previous studies on the effects of colony demographic structure on division of labor that brood rearing division of labor also has behavioral response thresholds. That is, there is a ratio of brood pheromone to adult workforce above which colonies cannot increase the rate of growth due to constraints on amount of maximum number of larvae the adult workforce can support. In such a case, it is expected that colony brood rearing and rate of growth will not increase but adjust to the available workforce (SchmidHempel et al. 1993). In colonies treated with high amounts of brood pheromone every level of brood rearing division of labor is expected to be affected, such as decreased age of first foraging (Le Conte et al. 2001), and decreased amount of brood rearing.

Acknowledgements Appreciated assistance was provided by Stephanie Walkup-Birkhead, Robert Vaughn, GW Burlin and Brad Metz. This research was supported by grants from the USDA/NRI 200435302-15031 to T Pankiw, as well as support from the Texas Honey Bee Legislative Initiative. Bees were handled in compliance with current laws of the United States of America.

Open Access This article is distributed under the terms of the Creative Commons Attribution Noncommercial License which permits any noncommercial use, distribution, and reproduction in any medium, provided the original author(s) and source are credited.

\section{References}

Allen MD (1960) The honeybee queen and her attendants. Anim Behav 8:201-208

Al-Tikrity WS, Benton AW, Hillman RC, Clarke WW Jr (1972) The relationship between the amount of unsealed brood in honeybee colonies and their pollen collection. J Apic Res 11:9-12

Brouwers EVM (1982) Measurement of hypopharyngeal gland activity in the honeybee. J Apic Res 21:193-198

Brouwers EVM (1983) Activation of the hypopharyngeal glands of honeybees. J Apic Res 22:137-141

Camazine S (1993) The regulation of pollen foraging by honey bees: how foragers assess the colony's need for pollen. Behav Ecol Sociobiol 32:265-272

Chauvin R (1956) Les facteurs qui gouverment la ponte chez la reine des abeilles. Insect Soc 3:499-504

Crailsheim K, Schneider LHW, Hrassnigg N, Buhlmann G, Brosch U, Gmeinbauer R, Schoffmann B (1992) Pollen consumption and utilization in worker honey bees (Apis mellifera carnica): dependence on individual age and function. J Insect Physiol 38:409-419

Danka RG, Rinderer TE, Collins AM, Hellmich II (1987) Responses of Africanized honey Bees (Hymenoptera: Apidae) to pollination- management stress. J Econ Entomol 80:621-624

Dreller C, Tarpy DR (2000) Perception of the pollen need by foragers in a honey bee colony. Anim Behav 59:91-96

Eckert CD, Winston ML, Ydenberg RC (1994) The relationship between population size, amount of brood, and individual foraging behaviour in the honey bee, Apis mellifera L. Oecologia 97:248-255

Fefferman NH, Starks PT (2006) A modeling approach to swarming in honey bees (Apis mellifera). Insect Soc 53:37-45

Fewell JH, Winston ML (1992) Colony State and regulation of pollen foraging in the honey bee, Apis mellifera L. Behav Ecol Sociobiol 30:387-393

Free JB (1967) Factors determining the collection of pollen by honeybee foragers. Anim Behav 15:134144 
Free JB (1979) Managing honeybee colonies to enhance the pollen-gathering stimulus from brood pheromones. Appl Anim Ethol 5:173-178

Free JB, Williams IH (1972) The influence of a honeybee (Apis mellifera) colony on egg-laying by its queen. Entomol Exp Appl 15:224-228

Gary NE, Lorenzen K (1976) A method for collecting the honey-sac contents from honeybees. J Apic Res 15:73-79

Houston AI, Schmid-Hempel P, Kacelnik A (1988) Foraging strategy, worker mortality and the growth of the colony in social insects. Am Nat 131:107-114

Hrassnigg N, Crailsheim K (1998) Adaptation of hypopharyngeal gland development to the brood status of honeybee (Apis mellifera L.) colonies. J Insect Physiol 44:929-939

Huang ZY, Otis GW (1989) Factors determining hypopharyngeal gland activity of worker bees (Apis mellifera L.). Insect Soc 36:264-276

Huang ZY, Otis GW (1991) Inspection and feeding of larvae by worker honey bees (Hymenoptera: Apidae): effect of starvation and food quality. J Insect Behav 4:305-317

Huang ZY, Robinson GE (1996) Regulation of honey bee division of labor by colony age demography. Behav Ecol Sociobiol 39:147-158

Huang ZY, Otis GW, Teal PEA (1989) Nature of brood signal activating the protein synthesis of hypopharyngeal gland in honey bees, Apis mellifera (Apidae: Hymenoptera). Apidologie 20:455-464

Le Conte Y, Mohammedi A, Robinson GE (2001) Primer effects of a brood pheromone on honeybee behavioural development. Proc R Soc Lond B 268:1-6

Lee PC, Winston ML (1987) Effects of reproductive timing and colony size on survival, offspring colony size and drone production in the honey bee (Apis mellifera L.). Ecol Entomol 12:187-195

Lindauer M (1952) Ein Beitrag zur Frage der Arbeitsteilung im Bienenstaat. Z Vergl Physiol 34:299-345

Mohammedi A, Crauser D, Paris A, Le Conte Y (1996) Effect of a brood pheromone on honeybee hypopharyngeal glands. Comptes Rendus de l' Académie des Sciences Paris, Sciences de la vie 319:769-772

Pankiw T (2004a) Brood pheromone regulates foraging activity of honey bees (Hymenoptera: Apidae). J Econ Entomol 97:748-751

Pankiw T (2004b) Cued in: honey bee pheromones as information flow and colony decision-making. Apidologie 35:217-226

Pankiw T (2004c) Worker honey bee pheromone regulation of foraging ontogeny. Naturwissenschaften 91:178-181

Pankiw T (2007) Brood pheromone modulation of pollen forager turnaround time in the honey bee (Apis mellifera L.). J Insect Behav 20:173-180

Pankiw T, Page RE (2001) Brood pheromone modulates sucrose response thresholds in honeybees (Apis mellifera L.). Behav Ecol Sociobiol 49:206-213

Pankiw T, Rubink WL (2002) Pollen foraging response to brood pheromone by Africanized and European honey bees (Apis mellifera L.). Ann Entomol Soc Am 95:761-767

Pankiw T, Page RE, Fondrk MK (1998) Brood pheromone stimulates pollen foraging in honey bees (Apis mellifera). Behav Ecol Sociobiol 44:193-198

Pankiw T, Roman R, Sagili RR, Zhu-Salzman K (2004) Pheromone-modulated behavioral suites influence colony growth in the honey bee (Apis mellifera). Naturwissenschaften 91:575-578

Pankiw T, Sagili RR, Metz BN (2008) Brood pheromone effects on colony protein supplement consumption and growth in the honey bee (Hymenoptera: Apidae) in a subtropical winter climate. J Econ Entomol 101:1749-1755

Sagili RR, Pankiw T, Zhu-Salzman K (2005) Effects of soybean trypsin inhibitor on hypopharyngeal gland protein content, total midgut protease activity and survival of the honey bee (Apis mellifera $\mathrm{L}$.). J Insect Physiol 51:953-957

SAS (2000) The SAS system version 8.01. SAS Institute, Cary, NC

Schmickl T, Blaschon B, Gurmann B, Crailsheim K (2003) Collective and individual nursing investment in the queen and in young and old honeybee larvae during foraging and non-foraging periods. Insect Soc 50:174-184

Schmid-Hempel P, Winston ML, Ydenberg RC (1993) Invitation paper (C.P. Alexander fund): Foraging of individual workers in relation to colony state in the social hymenoptera. Can Entomol 125:129-160

Seeley TD, Kolmes SA (1991) Age polyethism for hive duties in honeybees - illusion or reality. Ethology $87: 284-297$

Sokal RR, Rohlf FJ (1995) Biometry: the principles and practice of statistics in biological research, 3rd edn. Freeman, NY

Winston ML (1987) The biology of the honey bee. Harvard University Press, Cambridge, MA 